\author{
AGATA PALIWODA \\ (D) https://orcid.org/0000-0003-4043-6557 \\ Uniwersytet Rzeszowski \\ Rzeszów
}

\title{
Nowy Jork w prozie Janusza Głowackiego
}

\author{
New York in the prose writings of Janusz Głowacki
}

\begin{abstract}
The paper depicts the image of New York which emerges from the prose writings of Janusz Glowacki. The writer, meticulous in representing the topography of the metropolis, saw it as a city of stark contrasts, unlimited possibilities and complete unpredictability. The view of New York, always critical in Głowacki's writing, revealed its sharpness and depth especially in his recent novels. The city appears as a parable of the global world, its chaos and confusion of values, as a reality, in which poverty and wealth exist next to each other, people devoid of authenticity treat others like objects, confrontation with otherness blurs identity, and values are created by money and the market
\end{abstract}

Keywords: Janusz Głowacki, prose, New York, emigration

Nowy Jork, obok Warszawy, stanowi najważniejsze miasto na przestrzennej mapie twórczości Janusza Głowackiego. Korzystając z propozycji badawczej Małgorzaty Czermińskiej, powiedzieć można, że wykreował on Nowy Jork jako swoje miejsce autobiograficzne ${ }^{1}$. Miasto to pojawiło się w życiu Głowackiego, a potem jego twórczości, na skutek podyktowanych historią zdarzeń. Pisarz, co często wspominał w wywiadach, w grudniu 1981 roku poleciał do Londynu na premierę swojej sztuki Kopciuch w Royal Court Theatre, a rok później - w konsekwencji wprowadzenia w Polsce stanu wojennego - znalazł się w Stanach Zjednoczonych, gdzie nieprzerwanie mieszkał (głównie w Nowym Jorku) do 1989 roku². Od tego czasu najpierw

1 Badaczka miejsce autobiograficzne definiuje jako „znaczeniowy, symboliczny odpowiednik autentycznego miejsca geograficznego oraz związanych z nim kulturowych wyobrażeń” (Czermińska 2011, 188).

2 W $Z$ głowy pisarz wspominał, że przed 1983 r. w USA był dwa razy: uczestniczył w Międzynarodowym Programie dla Pisarzy na Uniwersytecie w Iowa, a wkrótce potem otrzymał 
w Polsce bywał, potem znów związał się z Warszawą, ale Nowy Jork regularnie odwiedzał, tam też osiadła jego jedyna córka.

Twórca nie planował emigracji, ona mu się ,przytrafiła”, ale kiedy już stała się faktem, wybrał Amerykę (a ściślej właśnie Nowy Jork³), tę - jak ją nazywał - „ziemię obiecana, ale niekoniecznie dla wszystkich” (Głowacki 2004, 81). Zatem w dorobku literackim Głowackiego Nowy Jork to także pozostając w obszarze przywołanych ustaleń - „przesunięte miejsce autobiograficzne”, które pojawia się, wówczas gdy emigrant znajduje jaką́s „drugą ojczyznę, w której się osiedla i którą akceptuje przynajmniej do tego stopnia, że znajduje dla niej miejsce w swojej twórczości" (Czermińska 2011, 195).

Janusz Głowacki od początku lat sześćdziesiątych, gdy zaistniał w polskim życiu literackim, a szczególnie wyraziście od roku 1968, kiedy to wydał zbiór opowiadań Wirówka nonsensu, aż do śmierci konsekwentnie demaskował absurdy czasów, w jakich przyszło mu żyć ${ }^{4}$. Wydaje się, że wyjazd z kraju i zmaganie się z nowymi amerykańskimi realiami (choć to momenty trudne w jego biografii), a następnie powrót do „odrodzonej” Polski - nie zmieniły zasadniczo ukształtowanego w czasach PRL-u sposobu oglądu świata, wrażliwości ani tė̇ metod artystycznego przetwarzania rzeczywistości, które wcześnie wykrystalizowane, stanowiły wyrazisty i bezbłędnie rozpoznawany styl pisarza ${ }^{5}$. Charakteryzuja go m.in.: ironia, także autoironia, lekko skrywany cynizm, skłonność do groteski, dezynwoltura, operowanie banałem, kalamburem oraz sloganem, upodobanie do stylizacji, głównie parodii, pastiszu oraz innych intertekstualnych nawiązań i wreszcie humor - niekiedy wisielczy (Gosk 1996, 35). Badacze zgodnie podkreślają znakomity słuch językowy pisarza, pozwalający tropić mu nowomowę, środowiskowe slangi, mowe potoczna, po to, by pokazać, jak te języki kształtują i fałszują obraz świata. Spoistość jego postawy wyznaczają też, jak to formułował Henryk Bereza (1997, 61), przyjaciel i wierny krytyk twórczości Głowackiego: antyestetyzm polegający na odrzuceniu estetycznych konwenansów, antypate-

stypendium Departamentu Stanu, które pozwoliło mu nieco zobaczyć i poznać Stany Zjednoczone (Głowacki 2004, 64).

3 Głowacki pisał: „Do głowy mi nie przychodziło, że Ameryka to się zrobi mój kraj” (2004, 65). Mówił: „Gdyby mi się nie zdarzyła Ameryka, to nie wiadomo jakby ze mną było, pewnie wpadłbym w alkoholizm (...)” (Bartosz 2018, 13).

4 Taką ,postawę” Głowackiego pokazuje również jego ostatnia książka, opracowana już po śmierci pisarza przez jego żonę, Olenę Leonenko-Głowacką, Bezsenność w czasie karnawału (Głowacki 2018).

5 Prozę emigracyjną twórcy szerzej omawiam w artykule „Zapisać strach przed zidioceniem świata”. Uwagi o prozie Janusza Głowackiego (Paliwoda 2007, 231-244). 
tyczność i antyideologizm, niemający w sobie nic z nihilizmu. O swoistej jednorodności twórczości pisarza można mówić także dlatego, że posługuje się często techniką autoadaptacji wobec swoich wcześniej napisanych tekstów, „rekombinując ich pierwotną treść, język i formę gatunkową” (Popczyk-Szczęsna 2015, 9).

Kiedy Głowacki tematyzuje bycie emigrantem - zaś zagadnienie „emigracyjności" rozpatruje w szerszej płaszczyźnie uniwersalnych problemów ludzkiej egzystencji, ukazuje procesy destabilizacji dotychczasowego porządku, także w sferze aksjologii, z przeżyciem zjawiska przemocy w skali jednostkowej i zbiorowej ze społeczną alienacją i wykorzenieniem (Paliwoda 2007, 236) - Nowy Jork pojawia się jako tło zdarzeń, a nawet swoisty „,bohater" zarówno dramatów, powieści, opowiadań, jak i felietonów oraz fabularyzowanych wspomnień ${ }^{6}$. Do najsłynniejszego miasta świata pisarz żywił mieszane uczucia - „z jednej strony je kocham, z drugiej strasznie się w nim męczę" - takie wyznanie pojawiło się w portretującym autora Ostatniego ciecia opracowaniu Izy Bartosz $(2018,26)$. Twórca, próbując więc uchwycić genius loci Wielkiego Jabłka, przekonuje, że to zadanie arcytrudne, a potoczne wyobrażenia o nim w żaden sposób nie zbliżają do istoty fenomenu tej metropolii: „Polacy wiedzą wszystko o Nowym Jorku z filmów, pocztówek, ale to jest taka wiedza jak o Monie Lizie. Wiadomo, że się uśmiecha, ale nie wiadomo dlaczego i co ten uśmiech ma oznaczać" (Głowacki 2004, 77).

Z różnych tekstów Głowackiego wyłania się obraz „za dużego miasta” dla stałych mieszkańców, a już na pewno dla tych emigrantów, których pisarz znał, których losem się przejmował i których historie z artystycznym oraz komercyjnym sukcesem opracowywał literacko, by wspomnieć tylko Polowanie na karaluchy ${ }^{7}$ czy Antygone w Nowym Jorku. Nowy Jork to także miasto wielkich kontrastów, nieograniczonych możliwości, ale też całkowitej nie-

${ }^{6}$ Głowacki jest też autorem tekstu do albumu ze zdjęciami Nowego Jorku Jerzego Habdasa. Wydawnictwo to zostało pomyślane - wyjaśniał pisarz - jako rodzaj hołdu złożonego miastu po tragedii 11 września 2001 r. przez zafascynowanych nim artystów (Habdas 2001, 5).

7 Głowacki wspominał: „Po entuzjastycznej recenzji Franka Richa z Polowania na karaluchy w Manhattan Theatre Club na Off-Broadway, w którym Dianne Wiest grała w chwilę po otrzymaniu Oscara za rolę w filmie Woody'ego Allena Hannah i jej siostry, reżyser przedstawienia, Arthur Penn, powiedział, że ta recenzja jest warta pół miliona dolarów. I tak mniej więcej było, bo Karaluchy wystawiło ponad 50 teatrów w Ameryce, a potem poszła po całym świecie” (Głowacki 2019a, 314). Światowy sukces swoich sztuk „unaocznia” też pisarz w wyborze dramatów zatytułowanym Piẹc $i$ pót, publikując tam swoje fotografie ze znakomitymi reżyserami i aktorami, wcielającymi się w postaci z jego utworów scenicznych, oraz zdjęcia wycinków prasowych ze świetnymi recenzjami (Głowacki 2007). 
przewidywalności ${ }^{8}$. Rozpoznania i określenia, którymi próbował opisać nowojorskiego molocha, korespondują z opiniami znakomitych poprzedników pisarza na amerykańskim lądzie - równie mocno tym miastem oszołomionych. Głowacki chętnie się posiłkował ich poglądami. Czytamy: „Josif Brodski napisał, że budując to miasto, człowiek stworzył coś, nad czym w ogóle przestał panować. Isaac Bashevis Singer, zapytany o Nowy Jork, powiedział tylko jedno słowo: pośpiech" (Głowacki 2004, 77).

Skondensowany obraz miasta, o ile to w ogóle możliwe, zawarł pisarz w felietonie zatytułowanym NYC. Właściwie cały wart jest zacytowania, tym bardziej, że we wznowionym w 2019 r. zbiorze Jak być kochanym ma swoja premierę (Leonenko-Głowacka 2019, 377). Głowacki konsekwentnie eksponuje wymienione już wcześniej najważniejsze dla niego cechy metropolii: kontrast, różnorodność, ogrom, pośpiech. Przywołuje skrupulatnie nowojorskie adresy, które odzwierciedlały jego aktualne finansowe/społeczne położenie. Lokatorska wędrówka ze 196 ulicy, samego szczytu Manhattanu, za Harlemem, przez East Village, dzielnicę „,mocno artystyczną, ciągnącą się po wschodniej stronie Manhattanu, między 14 a 1 ulicą" (Głowacki 2019b, 366) aż do „tam, gdzie chciałem” - oznacza sukces. Pisze:

Teraz mieszkam nareszcie tam, gdzie chciałem, czyli na Upper West Side nad rzeką Hudson, tuż przy River Side Park, w którym gram w tenisa. No w ogóle miło, portierzy w uniformach itd. Na rogu 102 i Broadway, czyli 2 minuty ode mnie, jest kawiarnia $z$ ogromnymi oknami. A za nimi nieustajacy show: urzędnicy z Wall Street, wyprowadzacze psów, modelki, bezdomni i Japończycy przebrani za ninja. Niektórzy nazywają Nowy Jork kotłem, inni mozaika. Jedni i drudzy mają racje (Głowacki 2019b, 366).

Co ciekawe, pisarz swojemu emigracyjnemu sukcesowi sprawiającemu, że dla rodaków stał się jego ikoną (Popczyk-Szczęsna 2015, 8) poświęcił właściwie tylko jeszcze akapit w $Z$ glowy: „Kupiłem sportowa toyotę i nareszcie marnowałem pieniądze. Boże, jaka to była ulga! Odwoziłem córeczkę Zuzię do szkoły. Jechałem sobie, odbijałem się razem z samochodem w oknach sklepów, patrzyłem na Nowy Jork i myślałem sobie: «Mam cię»” (Głowacki 2004, 157). Tych pięć krótkich zdań to jedyny ślad radosnego tryumfu Gło-

\footnotetext{
8 „Nowy Jork jest nieprzewidywalny. Na ogół wszędzie wiadomo, komu się powinno udać, a komu nie. Tymczasem to gigantyczna kombinacja banków, teatrów, meczetów, urzędów imigracyjnych i kościołów, do których przytulają się niedbale zamaskowane domy publiczne. Widziała już klęski pewniaków i oszałamiające kariery stuprocentowych loserów” (Głowacki 2019b, 363).
} 
wackiego w mierzeniu się z Nowym Jorkiem, momentu, kiedy przeglądając się w - jak to nazywa Ewa Rewers - ekranach ponowoczesnego miasta (Rewers 1997, 41-50), widzi się zwycięzcą. Pisarz, świadomy, że sukces zdarza się tylko nielicznym - bo większość „gdzieś się gubi. Czasem coś tam o nich jeszcze słychać, że coś tam odkryli albo namalowali, napisali czy nakręcili. Albo kogoś zabili czy ktoś ich zastrzelił. Ale na ogół się rozpuszczają na dobre" (Głowacki 2004, 77) - eksponuje przede wszystkim dominujące w emigracyjnym doświadczeniu strach, biedę, ciężką pracę lub jej brak, tęsknotę za krajem i wreszcie bezdomność, zatem: upokorzenie i przegraną. Tym problemom twórczości Głowackiego badacze przyglądali się już z uwaga w szerszych i węższych kontekstach obrazu emigranta i Ameryki w literaturze polskiej (Dąbrowski 2013, 288-303; Adamczyk 2014, 77-78).

Jednak obraz Nowego Jorku, bycia w mieście, w prozie Głowackiego wyłania się nie z opisów aglomeracji widzianej przez szyby mknącego po szachownicy ulic samochodu, ale przede wszystkim z obserwacji wynikłych w trakcie jej pieszego przemierzania9 ${ }^{9}$, kiedy to „Obcy” spotyka się z wielokulturową „innością” (Ferenc 2012). Ewa Rybicka zauważa, że sytuacja przechodnia jest alegoria „człowieka miejskiego”, a „«ruchomy» status przechodnia sygnalizuje jego nomadyczną, nieustaloną i niezwiązaną z miejscem tożsamość" (Rybicka 2003, 210). W Bezsenności w crasie karnawału Głowacki pisze:

Ja wiem sporo o takim łażeniu niejasnym, bo tak łaziłem na początku emigracji w Nowym Jorku po 42 Ulicy, głównie od 5 Alei do 9 i z powrotem. Zapchanej krążącymi, łażącymi tak jak białymi, czarnymi, żółtymi. A pod ścianami uszminkowane twarze i przypudrowane piersi. (...). Erotyczne to było, aż dech zapierało, ale nie dla mnie, człowieka bez kasy. (...) Czyli na 42 ulicy, już nie mówię o dziewczynach, nawet szepty sprzedawców cracka mnie nie dotyczyły. Powrót do małego mieszkanka (...) też nie kusił. Więc łaziłem i się patrzyłem, bo a nuż coś wypatrzę. Wybierałem sobie $z$ tłumu trzy albo cztery osoby i się zastanawiałem, kim są i po co łażą" (Głowacki 2018, 52-53).

Pisarz, uznający podobnie jak Jean Baudrillard, „że nie ma nic bardziej intensywnego, elektryzującego, żywotnego i rwącego niż ulice Nowego Jorku"

${ }^{9}$ K. Szalewska cytuje Z. Herberta, który pisal, że flanowanie to „włóczenie się bez planu według perspektyw, a nie przewodników” i zauważa, że „tę dyrektywę mogłoby powtórzyć większość współczesnych twórców podejmujących temat miejski” (Szalewska 2015, 32). 
(Baudrillard 1998, 26), jest nimi wyraźnie zafascynowany. Chłonie jako przechodzień i widz (Gutorow 2006, 189) uliczny ruch, ludzką różnorodność, zapachy. Konsekwentnie nasyca swe teksty nazwami ulic, dokładnie lokalizuje je w przestrzeni, najczęściej - Manhattanu, który, jak wyjaśnia, ma mało wspólnego z resztą metropolii, podobnie jak Nowy Jork z Ameryka (Głowacki 2004, 77). Za Katarzyną Szalewską (2015) powiedzieć można, że Głowacki mapuje miasto ze względu na własne doświadczenia, pokazując czytelnikowi swój Nowy Jork, odzwierciedla jednostkowe trasy ${ }^{10}$.

Z pisarzem i m.in. z tak samo nazwanym bohaterem jego prozy (z cytowanej wcześniej Bezsenności w czasie karnawału), czy też z Januszem/Dżanusem i Dżerzim (z Good night, Ḋ̌erzı) - jako czytelnicy - przemieszczamy się po Nowym Jorku szczegółowo informowani o jego topografii ${ }^{11}$. W prozie Głowackiego nie tylko ulice, place, mosty, tunele, ale też nie-miejsca12: dworce, stacje metra, odsłaniają swoje tajemnice. Twórca prowadzi nas do lepszych i gorszych barów, restauracji oraz klubów - z tymi najbardziej ekskluzywnymi włącznie, wprowadza na mniej i bardziej eleganckie przyjęcia, do luksusowego penthouse'u na szczycie dwudziestopiętrowego wieżowca i porno-kina. Oprócz powszechnie znanych miejsc pokazuje/obnaża też nieturystyczny Nowy Jork. Migawkowo przywołuje mi.in.: znakomite adresy (np. pałacyk ambasady francuskiej na Piątej Alei przy Siedemdziesiątej Dziewiątej ulicy) i obraz parku ze śpiącymi na ławkach bezdomnymi. Informuje o ludziach koczujących kilka pięter pod stacjami metra, a po śmierci grzebanych w pięciowarstwowych grobach ${ }^{13}$ i portretuje ekspertów w garniturach od Armaniego, udających się do hotelu Hilton na konferencję poświęconą walce z głodem. W pomyślanej jako poszukiwanie śladów Kosiń-

10 „Włóczęga, reporter, flaner... Mapowanie polega więc na różnorodnych praktykach odrzucenia istniejącego planu miasta, według którego porusza się turysta, dystansu wobec systemu, wreszcie - promocji indywidualnej, subiektywnej mapy odzwierciedlającej jednostkowe trasy" (Szalewska 2015, 32).

11 Jak bardzo szczegółowo uzmysławiają fragmenty Good night, Dǐerz̨i (Głowacki 2010, 9, $78,107,249)$, ale ta sama skrupulatność charakteryzuje opisy Nowego Jorku zawarte choćby w skromnych objętościowo opowiadaniach Pole Garncarza czy też Sonia, która za dużo chciata (Głowacki 2011a) oraz w przywoływanych już wspomnieniach i felietonach.

12 A nie-miejsca właśnie - jak pisze M. Augé $(2008,129)$ - skazują ludzkość „na samotniczą indywidualność, na przechodniość, na prowizoryczność i efemeryczność”.

${ }_{13} \mathrm{~W}$ opowiadaniu Pole Garncarz̨a jeden z bohaterów, wyjaśniając koledze, że nowojorskie Potter's Field jest miejscem pochówku „kryminalistów, nędzarzy bez nazwiska, odrzutków...”, konkluduje: „Na Potter's Field jest przeludnienie. Grzebią w pięciu warstwach. To jest miasto najwyższych domów i najgłębszych grobów” (Głowacki 2011b, 29). 
skiego powieści penetruje podziemne labirynty korytarzy ze swoim bohaterem, który w klubach sado-maso w towarzystwie ścisłej elity „trzęsącej Nowym Jorkiem" (Sobolewska 2010, 86) odnajduje nie tylko dyskrecję, ale też miłosierdzie i - jak czytamy - człowieczeństwo. Pisarz rejestruje odpadające tynki i łuszczące się farby w bliskości lśniących fasad, szyb i luster „szaleńczo wertykalnego" miasta. Jednak na jego szczycie (a z pionowościa zawsze utożsamiany był święty wymiar przestrzeni) (Norberg-Schulz 2000, 21; Słonka 2006, 201) nie ma nic - co najwyżej oderwani od realnego świata bajecznie bogaci producenci filmowi sportretowani w czerni, bo pogrążeni w żałobie po śmierci (niewykluczone, że samobójczej) kota, „bo koty na Manhattanie są niemal zawsze w depresji” (Głowacki 2010, 10). Tak „ostatecznie” wartościowana jest nowojorska przestrzeń. Za jej interpretacyjna wykładnię posłużyć mogą słowa autora zapisane w innym miejscu: „Tak czy inaczej Nowy Jork to setki pięter w górę, ale też parę w dół (...). Na świetna imitację nieba zerka całkiem realne piekło" (Głowacki 2019b, 366).

Moloch w twórczości Janusza Głowackiego - a szczególnie w Ostatnim cieciu i w Good night Dizerzi, bo spojrzenie na Nowy Jork jest zawsze krytyczne, a w tych powieściach ujawniło całą swoją ostrość i głębię - jawi się parabola świata globalnego. Świata, w którym nędza i bogactwo sąsiadują ze sobą, ludzie pozbawieni autentyczności instrumentalnie posługują się innymi, konfrontacja z innością rozmywa tożsamość, a wartości kreowane sa przez rynek i pieniądz (Adamczyk 2014, 86). Tak jak w latach 60. i 70. pisarz potrafil rozpoznać oraz dać artystyczny wyraz splątaniu polskich postaw i skołtunieniu myśli, również i tu udało mu się ukazać zidiocenie, chaos i pomieszanie wartości współczesnego świata (Baniewicz 2016, 314), w czym „nowojorska perspektywa" okazała się szczególnie owocna.

\section{Bibliografia}

Adamczyk K., 2014, Koniec mitu. Ameryka emigrantów lat osiemdziesiatych, w: Nowacka B., Szałasta-Rogowska B., red., Literatura polska obu Ameryk. Studia i sұkice. Seria pierwsqa, Katowice Toronto.

Augé M., 2008, Nie-Miejsca. Wprowadzenie do antropologii nadnowoczesności: fragmenty, przeł. Dziadek A., „Teksty Drugie. Teoria literatury, krytyka, interpretacja”, nr 4 (112) http://baz hum.muzhp.pl/media//files/Teksty_Drugie_teoria_literatury_krytyka_interpretacja/Tekst y_Drugie_teoria_literatury_krytyka_interpretacja-r2008-t-n4_(112)/Teksty_Drugie_teoria_ literatury_krytyka_interpretacja-r2008-t-n4_(112)-s127-140/Teksty_Drugie_teoria_literatur y_krytyka_interpretacja-r2008-t-n4_(112)-s127-140.pdf [dostęp: 17.09. 2018].

Baniewicz E.,2016, Díanus. Dramatyczne praypadki Janusza Gtowackiego, Warszawa. 
Bartosz I., 2018, Świat bez Głowy. Portret Janusza Głowackiego, Warszawa.

Baudrillard J., 1998, Ameryka, przeł. Lis R., Warszawa.

Bereza H., 1997, Drieło, „Twórczość”, nr 1.

Czermińska M., 2011, Miejsca autobiograficzne. Propozycja w ramach geopoetyki, „Teksty Drugie. Teoria literatury, krytyka, interpretacja”, nr 5 (131).

Dąbrowski M., 2013, Literatura emigracyjna lat osiemdriesiatych. Perspektywa amerykańska: Gtowacki i inni, w: Czapliński P., Makarska R., Tomczok M., red., Poetyka migracji. Doświadczenie granic w literaturze polskiej przełomu XX $i$ XXI wieku, Katowice.

Ferenc T., 2012, Artysta jako Obcy. Socjologiczne studium artystów polskich na emigracji, Łódź.

Głowacki J., 2004, Z głowy, Warszawa.

Głowacki J., 2007, Pięć i pół, Warszawa.

Głowacki J., 2010, Good night, Dìeræi, Warszawa.

Głowacki J., 2011a, Sonia, która za dużo chciała. Wybór opowiadań, Warszawa.

Głowacki J., 2011b, Pole Garncarza, w: tegoż, Sonia, która za dużo chciała. Wybór opowiadań, Warszawa.

Głowacki J., 2018, Bezsenność w czasie karnawału, Warszawa.

Głowacki J., 2019a, Broadway, w: tegoż, Jak być kochanym, Warszawa.

Głowacki J., 2019b, NYC, w: tegoż, Jak być kochanym, Warszawa.

Gosk H., 1996, Summa literacka, „Nowe Książki”, nr 9.

Gutorow J., 2006, Nowojorskie ro:proszenie. O pewnej fascynacji Wallace'a Stevensa, w: Pyzik T., red., Wielkie tematy literatury amerykanskiej, t. 3, Miasteczka, miasta, metropolie, Katowice.

Habdas J., 2001, New York, Olszanica.

Leonenko-Głowacka O., 2019, Nota edytorska, w: Głowacki J., Jak być kochanym, Warszawa.

Norberg-Schulz C., 2000, Bycie, przestrzeń i architektura, przeł. Gadomska B., Warszawa.

Paliwoda A., 2007, „Zapisać strach prz̨ed zidioceniem świata”. Uwagi o prozie Janusza Gtowackiego, w: Andres Z., Pasterski J., Wal A., red., Proza polska na obczyźnie. Problemy - dyskursy - uzupetnienia, t. 2, Rzeszów.

Popczyk-Szczęsna B., 2015, Powtórzenia i powroty. O dramaturgii Janusz̨a Głowackiego, Katowice.

Rewers E., 1997, Ekeran miejski, w: Zeidler-Janiszewska A., red., Pisanie miasta - csytanie miasta, Poznań.

Rybicka E., 2003, Modernizowanie miasta: zarys problematyki urbanistycznej w nowoczesnej literaturze polskiej, Kraków.

Słonka M., 2006, (Do)chodzenie w Nowym Jorku. Perypatetyczne doswiadczanie miasta w „Szklanym mieście" Paula Austera, w: Pyzik T., Wielkie tematy literatury amerykańskiej, t. 3, Miasteczka, miasta, metropolie, Katowice.

Sobolewska J., 2010, Król upokorzeń, „Polityka”, nr 46.

Szalewska K., 2015, Retoryka bycia-w-mieście. Figury przestrzeni i myśli, w: Roszczynialska M., Wądolny-Tatar K., red., Nowe poetyki miejskie. Z problematyki urbanistycznej w literaturze XX $i$ XXI wiekeu, Kraków.

Agata Paliwoda - dr hab., Zakład Literatury Polskiej XX i XXI Wieku, Uniwersytet Rzeszowski, Rzeszów, Polska.

Jej zainteresowania naukowe dotyczą literatury współczesnej, a szczególnie literatury emigracyjnej, pogranicza kultur i popularnej. Jest autorką artykułów oraz szkiców opu- 
blikowanych w wydawnictwach zbiorowych i pismach naukowych, monografii Granice i pogranicza w powieściach Sergiusza Piaseckiego (Rzeszów 2009), "Swoja i obca”. Twórczość literacka Danuty Ireny Bieńkowskiej (Rzeszów 2015), a także współredaktorką książki Liryka żołnierska. Estetyka i wartości (Rzeszów 2011).

Kontakt: agatapaliwoda@gmail.com 